PBL IN SCHOOL PSYCHOLOGY TRAINING

\title{
Meeting Current Challenges in School Psychology Training: The Role of Problem Based Learning
}

\author{
Sandra Dunsmuir, Norah Frederickson and Jane Lang \\ University College London
}

Date Submitted: 02 October 2014

Date Accepted: 05 March 2017

Associate Editor: John Hitchcock

Correspondence concerning this article should be addressed to: Dr. Sandra Dunsmuir, Educational Psychology Group, Division of Psychology and Language Sciences, University College London, Gower Street, London WC1E 6BT. Email:

s.dunsmuir@ucl.ac.uk

[Type here] 
PBL IN SCHOOL PSYCHOLOGY TRAINING

\begin{abstract}
This article reports a national study of 13 of the 16 school psychology programs in the United Kingdom that utilize Problem Based Learning (PBL) approaches to train psychologists. Each program identified a key informant who could describe the strengths, weaknesses and possibilities for development of this instructional approach. Telephone interview transcripts were analyzed qualitatively, using thematic analysis procedures. Strengths identified included the compatibility of a PBL approach with existing program philosophy, the benefits of student self-directed learning to build generalizable knowledge, deal with uncertainly, enhance confidence, work collaboratively and integrate psychological theory and practice. Themes relating to the perceived weaknesses of PBL included assessment challenges, ensuring adequate time and curriculum coverage and issues relating to group dynamics. Adaptations made by programs delivering PBL involved updating content, revising structure, developing assessment and implementing tutor training in PBL facilitation. This study highlights the key lessons learned implementing PBL in one context, offering the potential to for SP trainers to develop this approach more widely.
\end{abstract}

Key Words: Training in School Psychology, Adult Assessment, International School Psychology, Professional Issues in School Psychology, Problem based learning, PBL

[Type here] 
PBL IN SCHOOL PSYCHOLOGY TRAINING

\section{Introduction}

Internationally, school psychology (SP) training is facing a range of important and common challenges. These include preparing graduate students for an extended breadth of practice requirements despite increasingly acute problems in program staffing, to the need to ensure that services are culturally appropriate and that school psychologists engage in evidence-based practice (Jimerson, Oakland \& Farrell, 2007). A clear illustration of the first of these challenges is provided by the increasing involvement of school psychologists in the overall promotion of child and adolescent mental health (Suldo, Freidrich, \& Michalowski, 2010; Ye \& Fang, 2010), including the delivery of therapeutic interventions (Atkinson, Squires, Bragg, Muscutt, \& Wasilewski, 2013; Yeo \& Choi, 2011). Alongside this, in recent years shortages of qualified program staff have been reported in nations where SP is a long established speciality (Clopton \& Haselhuhn, 2009), as well as in nations where the related training is still at a rudimentary stage (van Schalkwyk \& D'Amato, 2013).

The importance of ensuring that culturally appropriate SP services are offered to children and adolescents, their families and schools is recognized in relation to serving diverse indigenous groups (Akin-Little \& Little, 2013), supporting newly arrived immigrants (German, 2004; Haboush, 2007) and adapting models of practice imported from other countries (D'Amato, van Schalkwyk, Yang Zhao, \& Hu, 2013). Finally, Kratochwill (2007) identified a number of key challenges for graduate programs in preparing psychologists for evidence based school practice (American Psychological Association Task Force on Evidence-Based Practice for Children and Adolescents, 2008). These include integrating knowledge about evidence-based practice into curricula, extending models of research training, expanding training in problem solving consultation, and the application of prevention science in school contexts. Although all 
PBL IN SCHOOL PSYCHOLOGY TRAINING

of these training challenges are complex, they are also the kinds of challenges that some have argued Problem Based Learning (PBL) can address (Kennedy, Cameron \& Monsen, 2009).

\section{PBL in Professional Education}

PBL was developed at McMaster University Medical School in Canada in the late 1960s to deliver the academic elements of curricula and better integrate them with placement experiences (Barrows, 1996). It was adopted by a number of other medical schools internationally during the 1970s and has subsequently been used in across the health sciences, and in a range of less closely related areas, such as social work, engineering, architecture, business, law, economics, education and agriculture (Schwartz, Mennin, \& Webb, 2001). PBL was seen as more potentially able than conventional programs to address the needs of the $21^{\text {st }}$ century workplace in producing professionals able to keep abreast of developments in knowledge, apply it to practice problems and contribute it effectively in multi-professional team work contexts (Henlow \& Evensen, 2000). It was argued that PBL has a number of advantages over traditional programs in developing these additional abilities, such as addressing the problems of curriculum overload that are particularly acute in professional education, and meeting competency and accountability requirements, while supporting the development of a high level of critical analysis (Savin-Baden, 2000). Evaluative studies predominantly found that PBL use yields an advantage over conventional programs with respect to critical thinking (Sendag \& Odabasi, 2009), self-directed learning (Blumberg, 2000), problem solving and communication/team work (Koh, Khoo, Wong \& Koh, 2008). It should be noted that meta-analyses typically report that, compared to PBL, conventional instruction is associated with better short-term knowledge retention as measured by tests and examinations. However, this advantage

[Type here] 
PBL IN SCHOOL PSYCHOLOGY TRAINING

tends to reverse over time, with PBL consistently demonstrating superior outcomes with regard to long-term retention (Colliver, 2000; Dochy, Segers, Van den Bossche, \& Gijbels, 2003; Strobel, \& van Barneveld, 2009) and application of knowledge to practice (Gijbels, Dochy, Van den Bossche, \& Segers, 2005).

PBL can be applied to SP so that students become accustomed to addressing practitioner difficulties and challenges. Students work through a series of problem scenarios in small groups and in the process formulate goals for self-directed learning. Although the groups are tutor facilitated and usually guided by tutor provided procedural protocols, they are student led and so their functioning can be differentiated from student group discussion of casework in a conventionally taught course. Likewise, although seminars from experts may be included in a PBL program, these are not seen as a primary vehicle of curriculum delivery, but rather an efficient means of giving students access to a range of supporting information relevant to the learning needs identified from their initial small group work on a PBL scenario.

Different variants of PBL are identified in the literature, with the scheduling of lectures and other conventional elements by tutors being termed "hybrid PBL" (Armstrong, 1997, p. 137). Across different variants, Schmidt, Rotgans and Yew (2011) identified the core features of PBL as: the use of problems as triggers for learning, the engagement of students in small group collaboration, student initiation of learning under tutor guidance, and the scheduling of ample time for self-study, with limited inclusion of lectures.

\section{PBL in the Professional Training of Psychologists}

Despite the many benefits of PBL identified in published reviews and metaanalyses, its widespread use in medical and other health professions' training, and its identification as one of the most promising approaches for preparing SP trainees to meet

[Type here] 
PBL IN SCHOOL PSYCHOLOGY TRAINING

the demands of an increasingly challenging and uncertain work context (Kennedy et al., 2009), there have been few published accounts of the use of PBL in the professional training of applied psychologists. Two accounts of the adoption of PBL by clinical psychology training programs in the UK describe initial implementation of hybrid PBL programs (Nel et al., 2008; Stedmon, Wood, Curle, \& Haslam, 2005). These reports highlight the perceived value of the approach in the development of professional competences.

In the other published accounts, PBL is used in a circumscribed way, for example where its use is limited to addressing a particular aspect of the curriculum or to particular teaching contexts, such as providing opportunities for students to work in collaborative groups when geographically distant on placement. Kiernan, Murrell, and Relf (2008) described its introduction in a program for clinical and forensic psychologists in Australia where it was used only online in between residential schools on a distance learning program with the intention of enhancing the learning experience. A focus on the online use of PBL for a specific purpose is also apparent in the only published account of an application of PBL within SP (Bozic \& Williams, 2011). In this case, a single PBL scenario, focusing on service delivery issues in professional practice, was used each year to enable second year students to continue to work collaboratively following the start of an extended professional placement.

\section{The Present Study}

The context of the present study offered a unique opportunity to conduct a broadly based evaluation of the strengths and weaknesses of PBL implementation as perceived by experienced SP trainers. As Kennedy et al. (2009) detailed, PBL has been implemented in other professions because of the advantages it offers with regard to application of knowledge, skill development and group creative problem solving. PBL

[Type here] 
PBL IN SCHOOL PSYCHOLOGY TRAINING

is also useful for preparing for a professional role that is developing and a work context that is changing - all issues in SP training internationally. In the UK, the government commissioned report on the functions of school psychologists (Farrell et al., 2006) advocated an expanded role that would enable more effective contributions in applying psychology to maximise outcomes for children. The report also recommended the restructuring of initial professional training in SP from a one year Master's program with pre-requisite qualified school teaching experience and followed by a year of supervised practice, to an integrated three year doctorate. In the period prior to the launch of the doctoral training the universities involved collaborated with the professional body for psychology in the UK (the British Psychological Society) and the UK Higher Education Academy to organise a number of training and development initiatives, one of which focused on PBL models and methods. There was broad-based interest in the potential of PBL to address the challenges of equipping future school psychologists to fulfil the expanded role envisioned. Within the shared national context, the training on PBL provided a common stimulus and starting point. Not only were there common drivers across programs but situational factors also effectively nullified many previously identified barriers. For example, in moving from masters to doctoral level training university teams would be undertaking significant curriculum reorganisation and redevelopment, whether or not PBL was introduced.

This article reports a qualitative investigation which took advantage of this unique opportunity to investigate the experience of a national sample of SP trainers in implementing PBL and reporting on their perceptions of its strengths, weaknesses and possibilities for development. It complements the analysis of how PBL was used with doctoral school psychology trainees in the participating universities (reported in

[Type here] 
PBL IN SCHOOL PSYCHOLOGY TRAINING

Dunsmuir \& Frederickson, 2014). The study was designed to address the following research questions:

1. What appraisal of strengths and weaknesses do trainers offer from their use of PBL?

2. What adaptations to PBL design and delivery have programs made, or identified as needed, following a four year implementation period?

3. Are there patterns in the strengths and weaknesses identified across different levels of use of PBL?

\section{Method}

The research questions were addressed by using telephone survey methods to collect data from individuals involved in the design and facilitation of PBL within educational psychology doctoral training programs. Details about the participants and data collection procedures are presented below.

\section{Participants and Context}

The participants in this study were educators (known as program tutors) from thirteen of the sixteen universities in the UK that provide SP postgraduate training programs. The other three UK universities had elected not to formally adopt PBL as an approach when redesigning and extending the curriculum following the joint national training initiative, favoring more conventional methods (such as lectures and informal group work). Participants were nominated by heads of programs, who were contacted by e-mail and asked to identify a member of staff centrally involved with PBL curriculum design and delivery and could provide a knowledgeable perspective about the operation of PBL at their university. Of these thirteen participating tutors ( 9 female, 4 male), the majority (9 tutors) were aged between 50 and 59 years, two were aged $40-49$ years and

two were 30-39 years of age. All participants had post-graduate qualifications in 
PBL IN SCHOOL PSYCHOLOGY TRAINING

educational psychology ( 7 to doctoral, 6 to Masters level) and worked part-time in professional practice, in addition to working as an academic and professional tutor at their university.

All programs were accredited by the British Psychological Society, approved by the Health and Care Professions Council and based in universities compliant with the Quality Assurance Agency for Higher Education (QAA), the independent body responsible for standards and quality in higher education in the UK. The 13 participating universities were located in England (11), Scotland (1) and Northern Ireland (1). The three universities that opted not to adopt PBL were located in England (1), Scotland (1) and Wales (1) and did not differ from those that participated in any obvious way. The 16 universities offering professional training in SP the UK provide a collegiate support network which organizes termly meetings, an e-mail group and an annual joint training event. The authors of this study and its participants are all members of this network.

Participating universities recruit between 10 and 16 students each year on to professional doctorates in educational psychology. National datasets indicated that an average of $83 \%$ of recruits are female and $17 \%$ are male. Most students are aged between 20 and $29(70 \%)$, with around $21 \%$ aged $30-39$ years, $8 \%$ aged $40-49$ years and just $1 \%$ aged over 50 .

Preliminary information was collected about the context in which PBL was used in each participating university across the three year doctoral programs. All universities incorporated tutor specified lecture and seminar sessions, so implementing a hybrid PBL approach (Armstrong, 1997). However the universities varied on the extensiveness with which PBL was used across the academic curriculum. For eight universities the approach had been embraced as the basis for academic curriculum delivery in Year 1, and three of these continued use of the approach across Year 2 also. By contrast in the other five 
PBL IN SCHOOL PSYCHOLOGY TRAINING

universities its use was much more circumscribed. Two universities used it only during blocks of time away from the university on placement, incorporating use of information and communication technology, while three universities used it in one or two modules only. These three levels of use of PBL (as the basis of the academic curriculum in Years 1 and 2, as the basis of the academic curriculum in Year 1 only and in a supplementary manner for specific circumscribed purposes) were additionally used to consider interprogram differences in the patterns of strengths, weaknesses and desired developments identified in this study.

\section{Data Collection}

In order to elicit a comprehensive range of views, perceptions and reflections from program tutors, a semi-structured interview format was used. Telephone interviews were selected as these can enable flexible scheduling between geographically distanced participants (Sturges \& Hanrahan, 2004). Because the researchers (who conducted the interviews) and the participants had established professional relationships through membership of the national community of SP trainers, the documented disadvantages of telephone interviewing such as reduction of feedback cues (visual and nonverbal) and increased social remoteness were considered unlikely to inhibit disclosure of information. However, it should be noted that the researchers" "connoisseurship" (Patton, 2002, p. 179), where their expertise about SP and PBL assisted knowledge about what to ask, how to ask, and how to adapt because of the prior relationship with the participants, had to be balanced against the possibility of bias due to preformed opinions and expectations (reflexivity). This was addressed through the trustworthiness checks within the research design.

Consent was sought for the discussion to be audio-recorded and transcribed and participants were sent the questions in advance so that they could prepare responses (see

[Type here] 
PBL IN SCHOOL PSYCHOLOGY TRAINING

Appendix 1). The four central interview questions were formulated to address the broad research questions. The prompts were used after participants had raised issues relating to specific aspects of PBL implementation to ensure comparable coverage of content. Participants were informed that they would be e-mailed a transcript to provide an opportunity for review and editing for accuracy, if necessary. This is known as member checking (Nastasi \& Schensul, 2005). Assurances were provided that individuals would not be identifiable within any reports so as to maintain confidentiality. The two researchers each conducted an initial pilot interview after which transcripts were exchanged for review and discussion. Discussion and transcript scrutiny took place regularly throughout the process of conducting the interviews to ensure consistency of implementation and coverage. One researcher conducted six and the other, seven interviews, the duration of which ranged from 16 to 50 minutes.

\section{Data Analysis}

The text of the 13 transcripts was analyzed using a qualitative approach based on thematic analysis procedures described by Braun and Clarke (2006). A hybrid process of deductive and inductive thematic analysis was utilized (Fereday \& Muir-Cochrane, 2006). The initial pre-determined coding system was deductive, reflecting the focus of the semi-structured interview questions about the strengths, weaknesses and adaptations to PBL design and delivery on SP programs. In addition, new codes were derived from the data and formed the inductive sub-themes within the coding hierarchy (Guest, et al., 2012). This data-driven inductive approach followed Boyatzis (1998) and involved assigning a label to a theme, defining the theme and writing a descriptive statement relating to each theme to assist the coding process.

Trustworthiness of the data analysis was established through the process of coding two transcripts independently, then comparing the codes that were derived and 
PBL IN SCHOOL PSYCHOLOGY TRAINING

negotiating on the areas of disagreement. In order to promote credibility there was ongoing consultation between the two investigators to diminish researcher bias and selective attention. In addition, the member checking process provided participants with the opportunity to review the transcripts and provide any missing data. Dependability, or auditability, was ensured by the audio-recording and transcription of the interviews in their entirety. A software package for qualitative data analysis, ATLAS.ti (Muhr, 2004) was used to organize, review and revise the data within the telephone transcripts and to develop a conceptual network with easily accessible quotations. This enabled the researchers to review the thematic structure and check the internal consistency of the codes. Themes were evaluated by an independent experienced qualitative researcher in order to estimate the reliability (inter-rater agreement) in relation to the final coding frame. This was calculated following Miles and Huberman (1994) and found to be $92 \%$.

Once the final codes were established, thematic mapping (Braun \& Clarke, 2006) was undertaken. Atlas.ti software enables generation of concept maps in which network relationships are derived from co-occurring codes that are highlight where individual code quotations are in close proximity, embedded, overlapping or following each other (Friese, 2012). This process enables the development of a coherent, visual account of the results (see Figure 1 below). The use of Atlas.ti software to assist this process provides an empirical basis (i.e. frequency of co-occurring codes), which is subject to veracity checking though independent review by the two researchers and member checking (or respondent validation) with four selected participants. This involved returning coded manuscripts to affirm that these accurately summarized the key issues identified for that program. Aside from some typographic issues that were identified, all four participants agreed the accuracy of the transcript in representing their views and affirmed that the coding system captured key themes.

[Type here] 
PBL IN SCHOOL PSYCHOLOGY TRAINING

\section{Results}

Thematic analysis yielded a coding hierarchy with three main themes relating to the perceived strengths, weaknesses and developments in PBL, following four years of implementation. Within these themes emerged a series of related sub-themes which are presented in Table 1 along with exemplar quotations.

Table 1. PBL themes and subthemes with illustrative quotations

\begin{tabular}{|c|c|c|}
\hline Theme & Definition & Illustrative quotations \\
\hline \multicolumn{3}{|l|}{$\begin{array}{l}\text { Strengths of } \\
P B L\end{array}$} \\
\hline $\begin{array}{l}\text { S.1. } \\
\text { Compatible } \\
\text { with Program } \\
\text { Philosophy }\end{array}$ & $\begin{array}{l}\text { Consistency of } \\
\text { PBL with existing } \\
\text { pedagogic theory } \\
\text { and practice }\end{array}$ & $\begin{array}{l}\text { "PBL pedagogy sits very well within a social, } \\
\text { constructivist view of learning where the learners } \\
\text { are taking the more active part in developing } \\
\text { their understanding and sharing their } \\
\text { experiences and learning from each other in a } \\
\text { collaborative way." }\end{array}$ \\
\hline $\begin{array}{l}\text { S.2. Self- } \\
\text { Directed } \\
\text { Learning }\end{array}$ & $\begin{array}{l}\text { Initiative for } \\
\text { learning needs, } \\
\text { goals and } \\
\text { activities rests } \\
\text { with students }\end{array}$ & $\begin{array}{l}\text { "...some of the strengths are to do with giving } \\
\text { the trainees scope to become more active in } \\
\text { their own learning and to pursue lines of enquiry } \\
\text { in a way in which they wish to." }\end{array}$ \\
\hline $\begin{array}{l}\text { S.3. Dealing } \\
\text { with } \\
\text { Uncertainty }\end{array}$ & $\begin{array}{l}\text { PBL assists } \\
\text { students manage } \\
\text { doubt and } \\
\text { apprehension }\end{array}$ & $\begin{array}{l}\text { "So I think it helps them to manage that } \\
\text { uncertainty and complexity. I think initially they } \\
\text { find that very difficult, but it grows over time as } \\
\text { they get more confident about not knowing } \\
\text { everything." }\end{array}$ \\
\hline $\begin{array}{l}\text { S.4. } \\
\text { Confidence } \\
\text { Building }\end{array}$ & $\begin{array}{l}\text { Students develop } \\
\text { self-assurance } \\
\text { through } \\
\text { experience of } \\
\text { PBL }\end{array}$ & $\begin{array}{l}\text { "I think there is something about that joint } \\
\text { working together which they get, which builds } \\
\text { confidence ... people who are quite reticent } \\
\text { within learning session activities that you carry } \\
\text { out, actually start coming out of their shell much } \\
\text { more when they are involved in the PBL" }\end{array}$ \\
\hline $\begin{array}{l}\text { S.5. } \\
\text { Knowledge/ } \\
\text { competence } \\
\text { building }\end{array}$ & $\begin{array}{l}\text { PBL assists } \\
\text { students develop } \\
\text { knowledge and } \\
\text { competence, } \\
\text { leading to } \\
\text { improved } \\
\text { capability }\end{array}$ & $\begin{array}{l}\text { "I think they get both subject specific skills and } \\
\text { knowledge and also transferable skills, like time } \\
\text { management, group work facilitation, listening to } \\
\text { other people etc. I think there is ongoing learning } \\
\text { in being critical and not believing and hearing } \\
\text { everything they see and being able to synthesise } \\
\text { and criticise information. They get exposed to a } \\
\text { wide range of information and have to evaluate } \\
\text { it.... well if it said this on this website, is it as valid } \\
\text { as something in a peer reviewed article? So they }\end{array}$ \\
\hline
\end{tabular}

[Type here] 
PBL IN SCHOOL PSYCHOLOGY TRAINING

\begin{tabular}{|c|c|c|}
\hline & & \\
\hline & & $\begin{array}{l}\text { are beginning to have to discriminate between } \\
\text { all that information out there in a sense." }\end{array}$ \\
\hline $\begin{array}{l}\text { S.6. } \\
\text { Collaboration }\end{array}$ & $\begin{array}{l}\text { PBL provides } \\
\text { opportunities for } \\
\text { students to work } \\
\text { cooperatively } \\
\text { together }\end{array}$ & $\begin{array}{l}\text { "...they have to adopt different roles, there will } \\
\text { be a Chair role, there will be a Scribe role and } \\
\text { they will turn take at those different opportunities } \\
\text { and those different roles. So it means they have } \\
\text { got the perfect practice working with others in a } \\
\text { collaborative manner, so it enskills them and } \\
\text { empowers them in team working, in managing a } \\
\text { group in... a very scaffolded and supported } \\
\text { manner" }\end{array}$ \\
\hline $\begin{array}{l}\text { S.7. } \\
\text { Integration of } \\
\text { Theory and } \\
\text { Practice }\end{array}$ & $\begin{array}{l}\text { PBL enables } \\
\text { students to } \\
\text { apply } \\
\text { psychological } \\
\text { theory to practice }\end{array}$ & $\begin{array}{l}\text { "So in a way, what PBL enables us to do is to } \\
\text { actually monitor students going beyond what is } \\
\text { covered in lectures, workshops or seminar } \\
\text { presentations, and to ensure that they are able } \\
\text { to demonstrate to us how they have managed to } \\
\text { synthesise theory and practice." }\end{array}$ \\
\hline $\begin{array}{l}\text { Weaknesses } \\
\text { of PBL }\end{array}$ & & \\
\hline $\begin{array}{l}\text { W.1. } \\
\text { Assessment }\end{array}$ & $\begin{array}{l}\text { Perceived } \\
\text { difficulties with } \\
\text { formative } \\
\text { assessment of } \\
\text { group products }\end{array}$ & $\begin{array}{l}\text { "...[students] felt a bit cheated really because } \\
\text { they felt that there were having to produce } \\
\text { something but it wasn't actually formally } \\
\text { assessed like other things on the timetable." }\end{array}$ \\
\hline $\begin{array}{l}\text { W.2. Content } \\
\text { Control }\end{array}$ & $\begin{array}{l}\text { Control over the } \\
\text { search for } \\
\text { content } \\
\text { knowledge rests } \\
\text { with students, } \\
\text { not educators }\end{array}$ & $\begin{array}{l}\text { "...we can't entirely control the contents, that are } \\
\text { covered and if something critical is missed we } \\
\text { try and pick it up later on within the timetable." }\end{array}$ \\
\hline $\begin{array}{l}\text { W.3. Group } \\
\text { Factors }\end{array}$ & $\begin{array}{l}\text { Variability in } \\
\text { quality of } \\
\text { learning } \\
\text { experience due } \\
\text { to influence of } \\
\text { group dynamics }\end{array}$ & $\begin{array}{l}\text { "The other thing is the makeup as a group, } \\
\text { because sometimes their experience very much } \\
\text { is dependent on who else is in the group with } \\
\text { them. If they have a group that works together } \\
\text { very constructively and positively then they } \\
\text { would probably view it as quite a positive and } \\
\text { constructive experience but if, for any reason, } \\
\text { the group dynamics aren't particularly conducive } \\
\text { to constructive learning then I think that has } \\
\text { been a barrier." }\end{array}$ \\
\hline W.4. Time & $\begin{array}{l}\mathrm{PBL} \text { is more time } \\
\text { consuming than } \\
\text { traditional } \\
\text { lectures }\end{array}$ & $\begin{array}{l}\text { "It is time consuming and I am not sure if I would } \\
\text { see that as a weakness or just more a practical } \\
\text { issue that we have. It is hard to get the balance } \\
\text { right between sufficient curricular coverage and } \\
\text { adequate time to work on PBL" }\end{array}$ \\
\hline
\end{tabular}

[Type here] 


\begin{tabular}{|c|c|c|}
\hline $\begin{array}{l}\text { Review and } \\
\text { Development } \\
\text { of PBL }\end{array}$ & & \\
\hline $\begin{array}{l}\text { R.1. Updating } \\
\text { and Revision } \\
\text { of PBL } \\
\text { Content }\end{array}$ & $\begin{array}{l}\text { PBL content and } \\
\text { resources } \\
\text { require regular } \\
\text { review and } \\
\text { revision }\end{array}$ & $\begin{array}{l}\text { "...we change the scenarios often especially if } \\
\text { something becomes current. So they do change } \\
\text { slightly but the core learnings I want them to get } \\
\text { out of it don't change." }\end{array}$ \\
\hline $\begin{array}{l}\text { R.2 Program } \\
\text { Specific } \\
\text { Developments }\end{array}$ & $\begin{array}{l}\text { Adaptations } \\
\text { made to deal } \\
\text { with varied } \\
\text { program } \\
\text { structures and } \\
\text { educational } \\
\text { methods } \\
\text { favoured }\end{array}$ & $\begin{array}{l}\text { "In year two we deliberately make both the } \\
\text { triggers and the finales a bit more open ended, } \\
\text { just because ... they will be dealing with more } \\
\text { uncertainty and more ambiguity and that is done } \\
\text { on purpose so that they are able to start } \\
\text { presenting and adapting their learning } \\
\text { accordingly. Then in year three... they } \\
\text { themselves decide on the actual finale and how } \\
\text { they present that back to their peers." }\end{array}$ \\
\hline $\begin{array}{l}\text { R.3 Tutor } \\
\text { Training }\end{array}$ & $\begin{array}{l}\text { To develop } \\
\text { knowledge and } \\
\text { competence with } \\
\text { PBL facilitation, } \\
\text { provision of } \\
\text { training is } \\
\text { needed for } \\
\text { program staff }\end{array}$ & $\begin{array}{l}\text { "... something we need to think through is the } \\
\text { role of the tutor facilitator... the first year we did } \\
\text { it, we were very much in touch with the process } \\
\text { but obviously as the years have gone on, what } \\
\text { has tended to happen is that different people are } \\
\text { teaching ..... and I think perhaps are not quite } \\
\text { in touch with the process as if they had been } \\
\text { part of the planning from stage one all the way } \\
\text { through... So maybe it is perhaps...offering PBL } \\
\text { training to new colleagues." }\end{array}$ \\
\hline
\end{tabular}

[Type here] 
PBL IN SCHOOL PSYCHOLOGY TRAINING

\section{Strengths of PBL (Research Question 1)}

The first strength of PBL (S.1) ${ }^{1}$ relates to its compatibility with the existing program philosophy and the theoretical orientation that was most frequently cited was social constructivism, a concept rooted in the work of Vygotsky (1978) that emphasises the role of social mediation in learning, and the growth of an individual's understanding as rooted in social encounters. Tutors elaborated on the strengths of active, self-directed learning (S.2) inherent in PBL and the benefits of building knowledge that is generalizable across contexts (academic and practice-based). The shift of the tutor role from didactic teacher to facilitator was raised by several tutors as being crucial to support effective student self-directed learning. The opportunities afforded for students to deal with uncertainly (S.3) as authentic PBL tasks served to expose students to the ambiguities and complexities that exist in SP practice were also highlighted. Another strength, raised by several tutors related to the way that PBL, over time was seen to build student confidence (S.4) in discussion and debate. The focused but nonjudgemental feedback provided as an aspect of the PBL process was seen as particularly important in achieving this.

In addition to increased confidence, tutors also mentioned students' increased professional knowledge and competence (S.5), for example in drawing on broad-based knowledge to develop and share hypotheses with regard to practice dilemmas and potential solutions and in developing process skills such critiquing and synthesising information. Opportunities for student collaboration (S.6) were considered beneficial in the development of group management and team working competencies. The development of transferrable, specific role competencies such as chair and scribe within a supportive, collaborative context were reported to be another strength of PBL. Finally,

\footnotetext{
${ }^{1}$ Parenthetical titles such as S.1 accompany reference to each theme to remind readers to refer to Table 1 for definitions and description.

[Type here]
} 
PBL IN SCHOOL PSYCHOLOGY TRAINING

integration between theory and practice (S.7) refers to the framework that PBL provides for applying psychological theory and research when dealing with issues that confront the students in practice.

\section{Weaknesses of PBL (Research Question 1)}

Tutors also described weaknesses of PBL. The first sub-theme, assessment (W.1), focuses on concerns about the appropriateness of summative assessment for work generated as part of a group process. Most programs had therefore opted to use formative assessment methods for PBL and these tended to be student-led, with a potential risk that a student could make very little contribution to the group effort, yet

still progress on the program: “...if somebody wanted to do 'PBL-light' they could skate through." A second weakness related to concerns about ensuring adequate curriculum coverage and the possibility that essential content may be missed during the PBL process, a sub-theme labelled content control (W.2). Group factors (W.3), more specifically issues to do with group dynamics, were considered to pose potential problems within PBL sessions. The variability of contributions by other group members was one issue identified and there were concerns about the impact on individual student learning of relationship problems occurring within groups. Finally, several tutors mentioned the time requirements of PBL and difficulties in ensuring that sufficient time was allocated (W.4).

The themes relating to strengths and weaknesses of PBL addressed research question 1. Themes that emerged relating to research question 2 are described below.

\section{Review and Development of PBL (Research Question 2)}

Having implemented PBL over four years, tutors identified adaptations they had made or were in the process of making, describing the ongoing updating and revision of PBL content (R.1) which was considered essential in order for stimulus materials to

[Type here] 
PBL IN SCHOOL PSYCHOLOGY TRAINING

maintain currency and relevance. Some programs focused on specific developments (R.2), for example one had varied the structure and delivery of PBL across the three years of training, steadily reducing the scaffolding provided to promote progression in levels of student decision-making and autonomy within the learning process. Another program had dealt with the assessment challenges by reviewing their methods and introducing a wider range of assessment approaches for use on placement. Finally, some participants had reviewed tutor training (R.3), revising the PBL facilitator role with program staff to ensure consistency and understanding of core requirements.

Figure 1. Thematic concept map of PBL implementation showing relationships between sub-themes

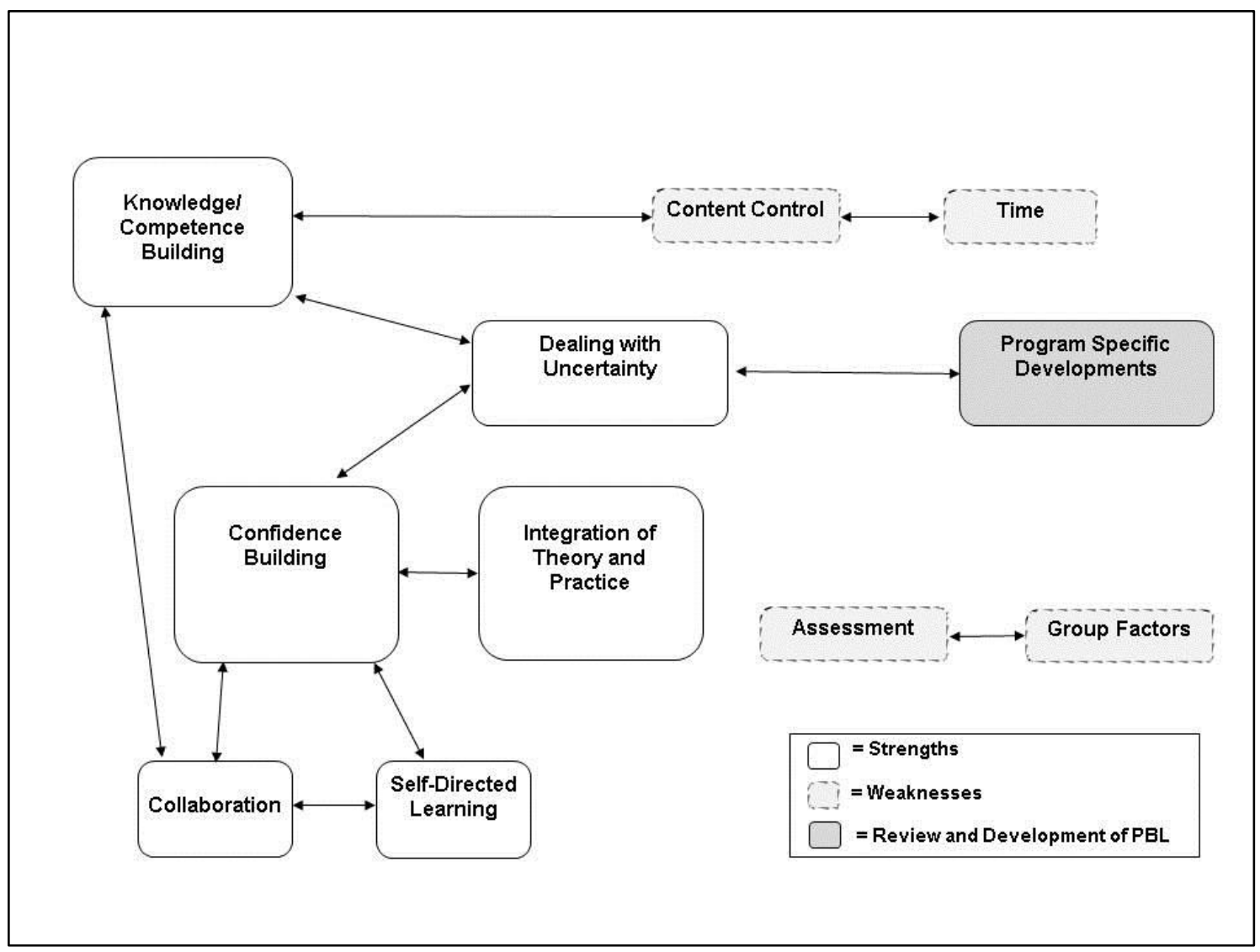

\section{PBL Thematic Map}

The thematic map was derived from examining all frequently co-occurring codes (i.e. associated issues mentioned by participants) and representing these visually (Friese, [Type here] 
PBL IN SCHOOL PSYCHOLOGY TRAINING

2012). This process is helpful in generating a visual representation of the aspects of PBL implementation that are linked and how this is related to participants' perceptions of strengths, difficulties and adaptations made. From the thematic map (Figure 1) it can be seen that there is an association between knowledge/competence building and dealing with uncertainty, indicating that as students become more knowledgeable and competent, they become more adept at handling ambiguity in professional practice. The link between confidence building and uncertainly similarly indicates that tutors report that as students progress with PBL, they become more confident when confronted with uncertain situations. Correspondingly, as students gain experience working in teams and engaging in self-directed learning, they become more confident in these aspects of practice. Collaboration within PBL is linked to the self-directed learning sub-theme as group processes underpin student prioritisation and definition of the focus of group study. Group members also collaborate to interpret and share different perspectives, knowledge and understanding in reaching a consensual view on how to progress (the association between knowledge/competence building and collaboration). The thematic map also highlights that PBL leads to improved student confidence in articulating how theory and practice are integrated, which can then be transferred from the university to the workplace.

There are changes in program organization over time so that more ambiguous PBL triggers, higher expectations about student decision making and reduced tutor facilitation are associated with improved ability to deal with uncertainty. The thematic map also shows that tutor concerns about knowledge building/competence are associated with concerns about lack of content control, concerns that could potentially be alleviated if additional time was allocated to PBL. Finally, the association between

[Type here] 
PBL IN SCHOOL PSYCHOLOGY TRAINING

assessment and group factors highlights the commonly held tutor perception of the difficulties involved in evaluating individual contributions to group assessments.

Patterns in the Strengths and Weaknesses Identified (Research Question 3)

In order to address research question 3, three levels relating to the extensiveness with which PBL was implemented across programs were identified: as the basis for delivery of the academic curriculum in Years 1 and 2 (three universities), in Year 1 only (five universities) and in a small number of specific circumscribed areas (five universities). Table 2 highlights the strengths and weaknesses of PBL that were identified, categorised according to these three levels of implementation.

[Type here] 
PBL IN SCHOOL PSYCHOLOGY TRAINING

Table 2. Strengths and Weaknesses of PBL Identified by Program Staff

PBL basis for

PBL basis for

Curriculum in Years

Curriculum in Year 1 only

Circumscribed use of PBL

$1 \& 2$

University

A B

C $\quad$ D $\quad$ E $\quad F$

F $\quad$ G

$\mathrm{H}$

\section{Strengths of PBL}

S.1. Compatible with Program Philosophy

S.2. Self-Directed Learning

S.3. Dealing with Uncertainty

S.4. Confidence Building

S.5. Knowledge/competence building

S.6. Collaboration

S.7. Integration of Theory and Practice

$\sqrt{ }$
$\sqrt{ }$
$\sqrt{ }$

\section{Weaknesses of PBL}

W.1. Assessment

W.2. Content Control

W.3. Group Factors

W.4. Time

\begin{tabular}{|c|c|c|c|c|c|c|c|c|c|c|}
\hline$\sqrt{ }$ & & $\sqrt{ }$ & & & & $\sqrt{ }$ & & & $\sqrt{ }$ & $\sqrt{ }$ \\
\hline$\sqrt{ }$ & $\sqrt{ }$ & & $\sqrt{ }$ & & $\sqrt{ }$ & $\sqrt{ }$ & & $\sqrt{ }$ & $\sqrt{ }$ & $\sqrt{ }$ \\
\hline$\sqrt{ }$ & & & & $\sqrt{ }$ & $\sqrt{ }$ & & & & $\sqrt{ }$ & $\sqrt{ }$ \\
\hline$\sqrt{ }$ & $\sqrt{ }$ & $\sqrt{ }$ & $\sqrt{ }$ & & $\sqrt{ }$ & & $\sqrt{ }$ & $\sqrt{ }$ & & \\
\hline$\sqrt{ }$ & $\sqrt{ }$ & $\sqrt{ }$ & $\sqrt{ }$ & $\sqrt{ }$ & $\sqrt{ }$ & & $\sqrt{ }$ & & $\sqrt{ }$ & $\sqrt{ }$ \\
\hline$\sqrt{ }$ & $\sqrt{ }$ & $\sqrt{ }$ & $\sqrt{ }$ & $\sqrt{ }$ & $\sqrt{ }$ & & & $\sqrt{ }$ & $\sqrt{ }$ & $\sqrt{ }$ \\
\hline$\sqrt{ }$ & $\sqrt{ }$ & & $\sqrt{ }$ & $\sqrt{ }$ & $\sqrt{ }$ & $\sqrt{ }$ & $\sqrt{ }$ & $\sqrt{ }$ & $\sqrt{ }$ & $\sqrt{ }$ \\
\hline
\end{tabular}


PBL IN SCHOOL PSYCHOLOGY TRAINING

Twelve of the thirteen programs reported that integration of theory and practice was a strength of PBL (the largest number); five programs identified dealing with uncertainty as a strength, representing the least cited of the strengths. It can be seen that all three groups were similar with regard to the strengths reported. However, a number of differences were apparent in relation to perceived weaknesses of PBL. Perhaps unsurprisingly, three of the programs that made circumscribed use of PBL considered time (W.4) to be a weakness. This was not mentioned by any of the programs that made extensive use of PBL across Years 1 and 2. A similar pattern was apparent in the identification of assessment as a weakness (W.1), with more of the programs using a circumscribed approach concerned about difficulties making individual assessments based on group products. By contrast, only one of the programs making circumscribed use of PBL saw content control (W.2) as a weakness, whereas the issue was raised by all three of the programs where PBL was used extensively, and for whom inadequate curriculum coverage was more of a concern. There were no concerns about group factors reported by programs that used PBL extensively across Years 1 and 2, in contrast to six of the programs at universities where PBL was implemented to a lesser extent.

In order to interpret patterns across the three levels of implementation, additional analyses were carried out on a subset of the data following findings previously reported by Dunsmuir and Frederickson (2014), which identified a number of dimensions along which the participating universities varied in their implementation of PBL (i.e., timetabling, training, grouping, documentation, and staffing). These were linked to qualitative identification of variations in practice, represented along dimensions with opposing poles (e.g., for Timetables, the poles range from one academic term to one week). Table 3 shows the hitherto unreported location on each of 


\section{PBL IN SCHOOL PSYCHOLOGY TRAINING}

these dimensions for each university involved in each of the three levels of PBL implementation. Each dimension (e.g. timetabling) was rated on a scale of 1 to 5 (e.g. 1= Extended [one term], 5 = Brief [less than a week]) and scores of 2, 3 and 4 were allocated to responses that fell between these two options. These were rated separately by the first author, a qualified and experienced school psychologist and trainer and the third author, an independent, experienced qualitative researcher. Good inter-rater reliability (88\%) was achieved (Dunsmuir \& Frederickson, 2014).

To begin to interpret Table 3, consider an example. See University A, which uses PBL in Years 1 and 2. Then see the Documentation row, and then Provision of References (see 4.2). The Provision of References Dimension can be rated from 'Routine in Unit' (a score of 5) to 'Sourced Only by Students' (a score of 1). University A was rated as a 2, meaning that references tended not to be routinely provided by tutors within each PBL unit. For another example, see 0.51 (Tutor Allocation). University Allocated one staff member for each PBL group; in contrast, other universities allocated only one tutor for an overall unit or PBL module (a score of 1).

[Type here] 
PBL IN SCHOOL PSYCHOLOGY TRAINING

Table 3. Key Factors identified by Program Staff in Implementation of PBL

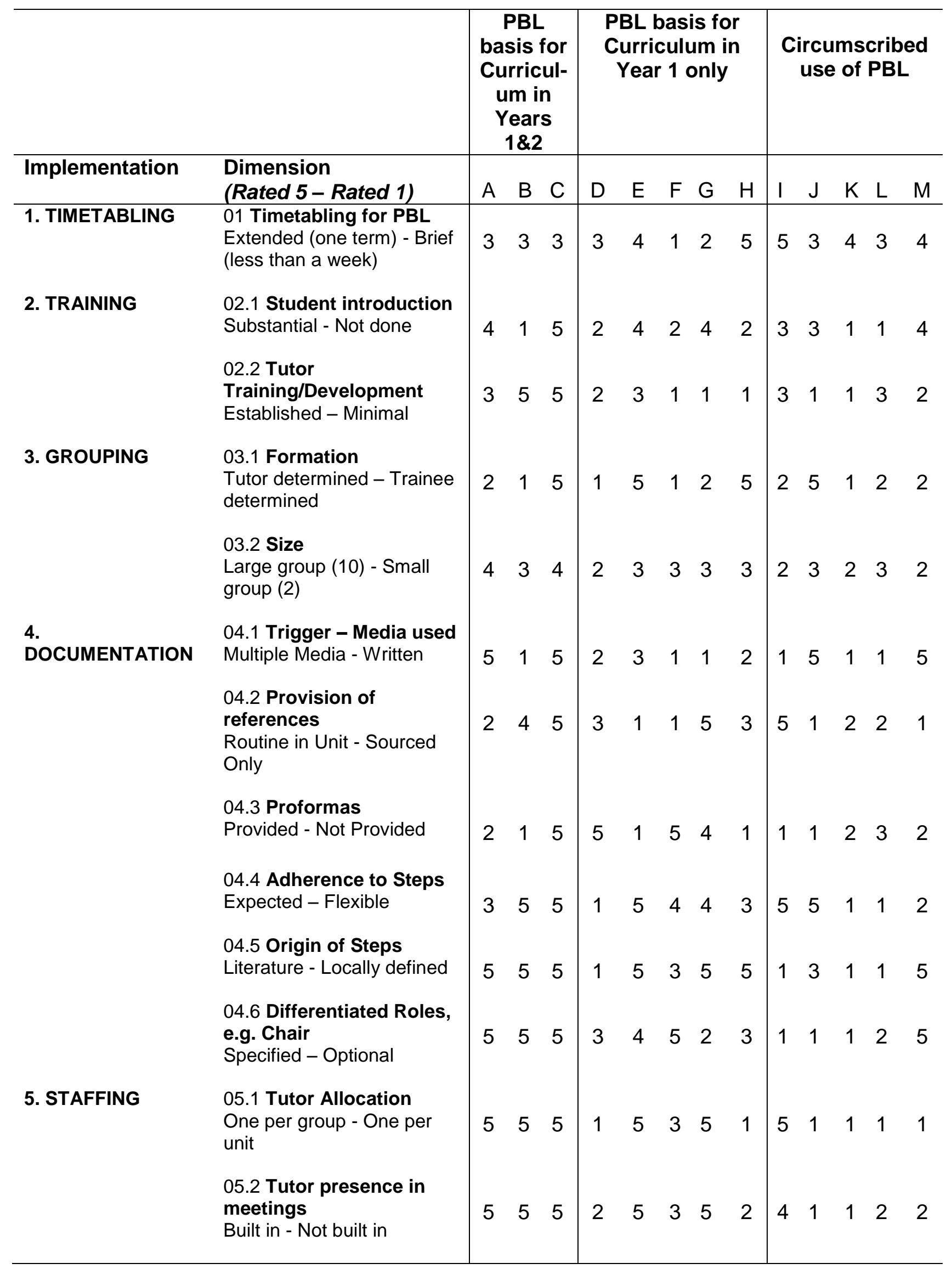

[Type here] 
PBL IN SCHOOL PSYCHOLOGY TRAINING

Table 3 therefore shows that programs making most extensive use of PBL (i.e. $\mathrm{A}, \mathrm{B}$, and $\mathrm{C}$ ) invested more resources, with a focus on training tutors (02.2), providing more intensive staffing (05.1 and 05.2), holding expectations of adherence to a stepped process derived from the literature on PBL (04.5) and requiring student role allocation (such as chair and scribe) within PBL groups (04.6). These factors provide structure, possibly to enhance consistency across the greater numbers of staff involved in PBL delivery. A lesser emphasis on tutor training (02.2) and reduced tutor allocation (05.1) is evident in programs that use PBL in Year 1 or for circumscribed purposes. Size of student PBL groups (03.2) appears to be independent of PBL implementation.

\section{Discussion}

This qualitative study provides a preliminary overview of the strengths, weaknesses and key adaptations to PBL design and delivery described by educators in thirteen SP doctoral programs in the UK. The strengths identified are congruent with PBL evaluations in a range of professional training. For example, in parallel with clinical psychology trainers who have advocated the approach (Baillie et al., 2011), tutors in this study described the psychological underpinnings of PBL in social constructivist terms and viewed the compatibility of this approach with the core program philosophy as a strength. Other strengths, such as students' growing ability to deal with uncertainty and engage in self-directed learning, were likewise reported in a systematic review of the impact of PBL on physician competency (Koh et al., 2008). Blumberg (2000) also described advantages of PBL over more traditional approaches in developing selfdirected learning,

Other work has found PBL to facilitate the development of critical thinking skills (Sendag \& Odabasi, 2009), here identified by tutors within the knowledge and competence built by the approach and associated with the integration of theory and [Type here] 
PBL IN SCHOOL PSYCHOLOGY TRAINING

practice, a core competence in SP training. Tutors also described how PBL enhanced student confidence, a finding supported by studies that have evaluated growth in confidence through student self-report (Mitchell, Canavan \& Smith, 2009). The development of student capability to work in teams and the benefits of collaboration with colleagues were additional strengths of PBL that have also been highlighted in previous studies (see Speck, 2003). However, problems with group dynamics or differential sharing of workload were seen as a downside of working in teams. There was little concern voiced about reduced acquisition of factual knowledge within PBL (Dochy et al., 2003), although the loss of control of curriculum content was considered to be a weakness.

Tutors identified problems with assessment and several participants indicated resistance to summative assessments of PBL products derived through group activity wherein it was difficult to appraise individual contributions. However summative assessment methods have been applied to PBL learning, for example multiple choice formats and modified essay questions have been widely used (Newman, 2003). It should be noted however that such assessments do not measure application of knowledge (Berkson, 1993) nor analysis and synthesis of information, skills that are much more relevant to real-life practice (Gijbels et al., 2005; Stedmon et al., 2005).

In seeking to explore whether any patterns exist in the strengths and weaknesses identified across different levels of use of PBL, the data suggested that programs making most extensive use of PBL were more likely to allocate higher levels of staff to PBL facilitation and to provide tutor training. Others researchers have reported that despite the provision of consistent training, considerable variability in time devoted to PBL tutoring can occur (Finucane, Nichols, Gannon, Runciman, Prideaux \& Nicholas, 2001), suggesting that provision of training and time devoted to PBL are not directly 


\section{PBL IN SCHOOL PSYCHOLOGY TRAINING}

related. Wood (2003) notes that the move from traditional curriculum delivery to implementation of PBL requires fundamental adaptations to timetabling, staff workload and assessment practices. It appears that the programs in this study that implemented PBL most extensively were more likely to develop resources to ensure greater adherence to the documented PBL stepped process described by Wolff (2000) and ensure that student roles (such as chair and scribe) were clearly defined and allocated. Simply put, intensive use of PBL requires commitment of resources and use of related strategies.

It is important to note some limitations to the assessment of the role of PBL in SP training undertaken in this study. While qualitative methods were appropriately used explore appraisals by experienced educators of the strengths and weaknesses of PBL, no external validating data (e.g. student perspective) were obtained that could have been used for triangulation. The participation of $80 \%$ of UK programs provides a comprehensive representation of the views of one community of SP trainers, however this is a community to which the authors belong and pre-existing professional relationships may have influenced the information obtained, for example through the operation of social desirability biases. In any case the conclusions drawn may not be generalizable to SP training in other contexts. Finally, as the context for this study involved changes in the length of training and level of award, as well as the introduction of PBL. It is possible that some of the effects attributed to PBL related to alternative or additional aspects of program change.

Finally, it must be acknowledged that the data reported in this article fall considerably short of being able to address Kennedy et al.'s (2009) claim that PBL is ideally placed to prepare new entrants for many of the challenges facing SP internationally. This would require an evaluation of training outcomes across PBL and 
PBL IN SCHOOL PSYCHOLOGY TRAINING

other curriculum models, attempting to control for the variations in curriculum delivery and the host of potential mediating variables typically identified in such research in other disciplines (Norman \& Schmidt, 2000). What this study does demonstrate is that PBL is a promising approach which was predominately positively evaluated by experienced SP trainers. It deserves more attention than it has hitherto received from the SP community internationally and its potential role in addressing some of our most pressing professional challenges warrants further investigation.

Future research designed to sample a range of additional variables (e.g. student views and outcomes with regard to knowledge and practice competence), adopt a crosscultural focus and examine associations with preferred learning approaches are a few of the potential future directions suggested by the UK SP trainers' experience. Finally, this article described PBL strengths, weaknesses and implementation considerations that SP trainers in other nations should ponder when conceptualizing their own approaches to training future school psychologists.

[Type here] 
PBL IN SCHOOL PSYCHOLOGY TRAINING

\section{References}

Akin-Little, A., \& Little, S. G. (2013). Rural schools serving indigenous populations: An international perspective on the provision of psychological services. School Psychology International, doi : 10.1177/0143034312446887

American Psychological Association Task Force on Evidence-Based Practice for Children and Adolescents. (2008). Disseminating evidence-based practice for children and adolescents: A systems approach to enhancing care. Washington, DC: Author.

Armstrong, E.G. (1997). A Hybrid Model of Problem Based Learning. In D. Boud, \& G. Feletti (Eds.), The challenge of problem based learning, (2nd ed., pp. 137-150). London: Kogan Page.

Atkinson, C., Squires, G., Bragg, J., Muscutt, J., \& Wasilewski, D. (2013). Facilitators and barriers to the provision of therapeutic interventions by school psychologists. School Psychology International, doi: 10.1177/0143034313485849 (in press).

Baillie, A.J., Proudfoot, H., Knight, R., Peters, L., Sweller, J., Schwartz, S. \& Pachana, N.A. (2011). Teaching Methods to Complement Competencies in Reducing the "Junkyard" Curriculum in Clinical Psychology, Australian Psychologist, 46, 90100. doi:10.1111/j.1742-9544.2011.00036.x

Barrows, H. S. (1996). Problem-based learning in medicine and beyond: A brief overview. In W. H. Gijselaers (Ed.), New directions for teaching and learning (pp. 3-11). San Francisco, CA: Jossey-Bass.

Berkson, L. (1993). Problem-based learning: Have the expectations been met? Academic Medicine, 68 (10 Suppl.), S79-S88. doi:10.1097/00001888-19931000000053

[Type here] 
PBL IN SCHOOL PSYCHOLOGY TRAINING

Blumberg, P. (2000). Evaluating the evidence that problem based learners are self directed learners: a review of the literature. In D. H. Evensen, \& C. E Henlow (Eds.), Problem based learning: A research perspective on learning interactions (pp. 199-226). Mahwah, N J: Lawrence Erlbaum Associates.

Bozic, N., \& Williams, H. (2011). Online problem-based and enquiry-based learning in the training of educational psychologists. Educational Psychology in Practice, 27(4), 353-364. doi: 10.1080/02667363.2011.590466

Boyatzis, R. (1998). Transforming qualitative information: Thematic analysis and code development. Thousand Oaks, CA: Sage.

Braun, V., \& Clarke, V. (2006). Using thematic analysis in psychology. Qualitative Research in Psychology, 3(2), 77-101. doi: 10.1191/1478088706qp063oa

Clopton, K.L., \& Haselhuhn, C.W. (2009). School psychology trainer shortage in the USA: Current status and projections for the future. School Psychology International, 30(1), 24-42. doi: 10.1177/0143034308101848

Colliver, J. A. (2000). Effectiveness of problem-based learning curricula: Research and theory. Academic Medicine, 75(3), 259-266. doi:10.1097/00001888-20000300000017

D'Amato, R.C., van Schalkwyk, G.J., Yang Zhao, B., \& Hu, J. (2013). Understanding the development of school psychology in Mainland China. School Psychology International, 34(2), 131-144. doi: 10.1177/0143034312453392

Dochy, F., Sagers, M., van den Bossche, P. \& Gijbels, D. (2003). Affects of problem based learning: a meta-analysis. Learning and Instruction, 13, 533 - 568. doi:10.1016/S0959-4752(02)00025-7

Dunsmuir, S. \& Frederickson, N. (2014). Problem Based Learning in Professional Training: Experiences of School Psychology Trainers in the UK. Training and

[Type here] 
PBL IN SCHOOL PSYCHOLOGY TRAINING

Education in Professional Psychology, 8(2), 127-135. doi:

10.1037/tep0000040DOI: 10.1037/tep0000040

Farrell, P., Woods, K., Lewis, S., Rooney, S., Squires, G. \& O’Connor, M. (2006). A Review of the Functions and Contribution of Educational Psychologists in England and Wales in light of "Every Child Matters: Change for Children". Nottingham, UK: DfES Publications.

Fereday, J., \& Muir-Cochrane, E. (2006). Demonstrating rigor using thematic analysis: A hybrid approach of inductive and deductive coding and theme development. International Journal of Qualitative Methods, 5(1), 80-92.

Finucane, P., Nichols, F., Gannon, B. Runciman, S., Prideaux, D. \& Nicholas, T. (2001). Recruiting problem-based learning (PBL) tutors for a PBL-based curriculum: the Flinders University experience. Medical Education, 35, 56-61.

Friese, S. (2012). Qualitative Data Analysis with ATLAS.ti. London: Sage.

German, M. (2004). Enabling reconnection: Educational psychologists supporting unaccompanied, separated, asylum-seeker/ refugee children. Educational and Child Psychology, 21(3), 6-29.

Gijbels, D., Dochy, F. Van den Bossche, P., \& Segers, M. (2005). Effects of problem based learning: a meta-analysis from the angle of assessment. Review of Educational Research, 75, 27-61. doi:10.3102/00346543075001027

Guest, G., MacQueen, K.M. \& Namey, E.E. (2012). Applied Thematic Analysis. London: Sage.

Haboush, K. L. (2007). Working With Arab American Families: Culturally Competent Practice for School Psychologists. Psychology in the Schools, 44(2), 183-198. doi:10.1002/pits.20215

[Type here] 
PBL IN SCHOOL PSYCHOLOGY TRAINING

Henlow, C. E., \& Evensen, D. H. (2000). Introduction to Problem Based Learning:

Gaining Insights on Learning Interactions through Multiple Methods of Enquiry. In

D. H. Evensen, \& C. E Henlow (Eds.), Problem based learning: A research perspective on learning interactions (pp. 1-16). Mahwah, NJ: Lawrence Erlbaum Associates.

Jimerson, S.R., Oakland, T.D. \& Farrell, P.T. (Eds.).(2007). The Handbook of International School Psychology. Thousand Oaks, CA: Sage.

Kennedy, E. K., Cameron, R. J., \& Monsen, J. (2009). Effective consultation in educational and child psychology practice: Professional training for both competence and capability. School Psychology International, 30(6), 603-625. doi: $10.1177 / 0143034309107079$

Kiernan, M. J., Murrell, E., \& Relf, S. (2008). Professional education of psychologists using online problem-based learning methods: Experience at Charles Stuart University. Australian Psychologist, 43, 286-292.

doi:10.1080/00050060802479553

Koh, G. C. H., Khoo, H. E., Wong, M. L., \& Koh, D. (2008). The effects of problembased learning during medical school on physician competency: A systematic review. Canadian Medical Association Journal, 178(1), 34-41. doi:10.1503/cmaj.070565

Kratochwill, T. R. (2007). Preparing psychologists for evidence-based school practices: Lessons learned and challenges ahead. American Psychologist, 62, 829-844. doi:10.1037/0003-066X.62.8.829

Little, S. G., Akin-Little, A., \&. Johansen, A. (2013). Bi-cultural Aotearoa/New Zealand: Provision of psychological services to the Māori population of rural New

[Type here] 
PBL IN SCHOOL PSYCHOLOGY TRAINING

Zealand: Combining best practice with cultural considerations. School Psychology International; vol. 34, 4: pp. 428-438. doi: 10.1177/0143034312446891

Loyens, S.M.M., Kirschner, P.A., Paas, F. (2012). Problem-based learning. In K. Harris, S. Graham, T. Urdan, A. G. Bus, S. Major, \& L.H. Swanson, (Eds.), APA educational psychology handbook, Vol 3: Application to teaching and learning. (pp. 403-425). Washington, DC: American Psychological Association

Miles, M.B., \& Huberman, A.M. (1994). Qualitative data analysis: an expanded sourcebook (Second edition). London: Sage Publications.

Mitchell, J., Canavan, B. \& Smith, J. (2009). Problem-based learning in communication systems: student perceptions and achievement. IEEE Transactions on Education, 53(4), 587-594. 10.1109/TE.2009.2036158. doi: 10.1109/TE.2009.2036158

Muhr, T. (2004). User's manual for ATLAS.ti 5.0. Berlin, Germany: ATLAS.ti Scientific Software Development GmbH.

Nastasi, B. K., \& Schensul. S. L. (2005). Contributions of qualitative research to the validity of intervention research. Journal of School Psychology, 43(3), 177-195. doi:10.1016/j.jsp.2005.04.003

Nel, P.W, Keville, S., Ford, D., McCarney, R., Jeffrey, S., Adams, S., \& Uprichard, S. (2008). Close encounters of the uncertain kind: Reflections on doing problembased learning (PBL) for the first time. Reflective Practice, 9(2), 197-206. doi: $10.1080 / 14623940802005582$

Newman, M. (2003). A Pilot Systematic Review and Meta-analysis on the Effectiveness of Problem Based Learning. Newcastle: Learning \& Teaching Subject Network for Medicine, Dentistry and Veterinary Medicine. Retrieved 05 April 2014 from the Economic and Social Research Council website: http://www.tlrp.org/dspace/retrieve/1389/pbl_report.pdf

[Type here] 
PBL IN SCHOOL PSYCHOLOGY TRAINING

Norman, G.R. \& Schmidt, H.G. (2000). Effectiveness of problem-based learning curricula: theory, practice and paper darts. Medical Education, 34, 721-8. doi: 10.1046/j.1365-2923.2000.00749.x

Patton, M. Q. (2002). Qualitative research and evaluation methods. Thousand Oaks, CA: Sage.

Savin-Baden, M. (2000). Problem based learning in higher education: untold stories.

Buckingham: The Society for Research into Higher Education and Open University Press.

Schmidt, H. G., Rotgans, J. I., \& Yew, E. H. J. (2011). The process of problem-based learning: What works and why. Medical Education, 45(8), 792-806. doi: $10.1111 / \mathrm{j} .1365-2923.2011 .04035 . \mathrm{x}$

Schwartz, P., Mennin, S., \& Webb, G. (Eds.) (2001). Problem based learning: Case studies, experience and practice. London: Kogan Page.

Sendag, S., \& Odabasi, H. F. (2009). Effects of an online problem based learning course on content knowledge acquisition and critical thinking skills. Computers \& Education, 53, 132-141. doi: 10.1016/j.compedu.2009.01.008

Speck, B. W. (2003). Fostering Collaboration Among Students in Problem-Based Learning. New Directions for Teaching and Learning, 95, 59-65. doi: $10.1002 / \mathrm{tl} .114$

Stedmon, J., Wood, J., Curle, C., \& Haslam, C. (2005). Development of PBL in the training of clinical psychologists. Psychology Learning and Teaching, 5, 52-60. doi: $10.2304 /$ plat.2005.5.1.52

Strobel, J., \& van Barneveld, A. (2009). When is PBL More Effective? A Metasynthesis of Meta-analyses Comparing PBL to Conventional Classrooms. Interdisciplinary Journal of Problem-Based Learning, 3(1), 44-58 .

[Type here] 
PBL IN SCHOOL PSYCHOLOGY TRAINING

Sturges, J.E., \& Hanrahan, K.J. (2004). Comparing telephone and face-to-face qualitative interviewing: A research note. Qualitative Research, 4, 107-118. doi: $10.1177 / 1468794104041110$

Suldo, S. M., Freidrich, A., \& Michalowski, J. (2010). Personal and systems-level factors that limit and facilitate school psychologists' involvement in school-based mental health services. Psychology in the Schools, 47(4), 354-373. doi:10.1002/pits.20475.

van Schalkwyk, G.J., \& D'Amato, R.C. (2013). Providing psychological services and counselling in Pacific Rim countries: Where is school psychology in Asia? School Psychology International, 34(2), 123-130. doi: 10.1177/0143034312453389

Vygotsky, L. S. (1978). Mind in Society: The Development of Higher Psychological Processes. Cambridge, MA: Harvard University Press.

Wolff, A. (2000). Problem based learning. The role of the tutor: A resource guide for faculty. Vancouver, Canada: Wolff Consulting Ltd.

Wood, D.F. (2003). Problem Based Learning. British Medical Journal, 326(7384), 328330.

Ye, Y. D., \& Fang, B. J. (2010). The development of school psychological services in the Chinese mainland: A Chinese perspective. School Psychology International, 31, 521-530, doi: 10.1177/0143034310382721.

Yeo, L. S., \& Choi, P. M. (2011). Cognitive-behavioural therapy for children with behavioural difficulties in the Singapore mainstream school setting. School Psychology International, 32(6), 616-631. doi:10.1177/0143034311406820.

[Type here] 
PBL IN SCHOOL PSYCHOLOGY TRAINING

\section{Author Biographical Statements}

Sandra Dunsmuir is Director of the Educational Psychology Group at University College London. She is also programme director of the UCL postgraduate courses in Cognitive Behaviour Therapy. Sandra has an interest in teaching and learning at all levels of the educational system. Her research publications focus on professional learning, relationships and communication and interventions to support children's literacy development and mental health.

Norah Frederickson is Emeritus Professor of Educational Psychology at University College London. Her research publications include the following areas: professional education in educational psychology, psychological assessment, applications of systems theory in education and factors influencing inclusion and belonging in school, in particular for children with special needs and disabilities.

Jane Lang is a Research Fellow with the Educational Psychology Group at UCL. In addition to collaborating on research projects, she supports educational psychology students in qualitative data analysis and the use of software packages. 


\section{PBL IN SCHOOL PSYCHOLOGY TRAINING}

Appendix 1.

Semi-structured interview outline

1. Can you describe how PBL is used on your program?

2. Is it used in particular areas/with particular year groups?

3. If I was to ask one of the trainees "What happens exactly in PBL at your university?" what would they say?

4. What do you and your colleagues feel are the strengths and weaknesses of PBL?

Prompts:

- Use of other methods - workshops, lectures, seminars?

- Proportion of time?

- Group size?

- Provision of stimulus material/reference lists?

- Assessment - self/peer/tutor, summative/formative, group/individual.

- Anticipated and observed outcomes for trainees/staff, for example in terms of self-directed learning or tutor time?

- Adaptations?

[Type here] 